\title{
Numbers are nice, but stories matter
}

$\mathrm{T}$ he media love a good story and the most important characteristic of a good story is bad news. Doctors at the Hospital for Sick Children in Toronto, Ontario, demonstrated this truth in 1991 with an elegantly simple study.

The doctors noticed 2 studies involving children, radiation and cancer had appeared simultaneously in JAMA. One study concluded that a hazard existed. The other said it did not. Since the media routinely report on findings from JAMA, how would they handle contradictory studies — good news and bad - published in the same issue?

They would favour the bad news, naturally. Of the 19 articles that reported on the studies, none mentioned the good news study alone; 9 discussed the bad without mentioning the good. Ten articles cited both studies — but all devoted more space to the bad-news study.

Death, disaster, destruction. The news is filled with it. Even the good news is bad. When Statistics Canada announced that the life expectancy of men had reached 80 years, the Toronto Star devoted precisely 1 sentence to this historic achievement, before rushing on to the really important news that "these booming ranks of elderly Canadians could crash our health system."

Complaints about the media's dour outlook are old news, of course. So are charges of sensationalism. Equally notorious is the media's obsession with novelty. And among physicians, scientists and others who work with numbers, the media's innumeracy is almost legendary.

Much less understood is why the media do the strange things they do.

The usual explanations involve money: scary, tragic and unusual stories attract readers and viewers and, by extension, advertisers. Some also see ideology at work: the media distort reality in order to push some agenda.

As a long-time journalist and observer of the media, I wouldn't dismiss these explanations entirely, but I do be- lieve they miss the more fundamental explanation, which is simply that the people who report the news are people.

Consider the media's obsession with man-bites-dog stories. One of the basic functions of the brain is to sift through an endless torrent of stimuli and distinguish between what must be brought to the attention of consciousness and what consciousness can safely ignore. In doing that, a key criterion used by the brain is novelty: anyone who reads a list of items written in blue ink will notice and remember the 1 item that's green. It's basic wiring.

The same is true of the media's fixation with bad news. Our brains are the product of ancient evolutionary pressures and in the Paleolithic environment it was a good idea to make imminent hazards - bad news — the top priority. When a band of humans was out picking berries on the African savanna, those who responded to a cry of "Lion!" by instantly forgetting the berries and running were more likely to survive and reproduce than those who kept picking berries, while calmly musing about the prevalence and hunting habits of lions.

Another essential element of human nature is storytelling. As evolutionary psychologists have shown, storytelling — both the telling and the listening — is a hard-wired human instinct. And the elements of a good story are always the same. It has to be about people. And it has to have novelty, drama and conflict.

Unlike stories, however, numbers do not come naturally to humans. "Sadly enough," writes neuroscientist Stanislas Dehaene, "innumeracy may be our normal human condition and it takes considerable effort to become numerate."2 Scientists like to say "anecdotes aren't data" but human nature actually sees things the other way around — numbers are nice but stories are truly meaningful.

What made sense in the Stone Age can trip us up in the Information Age. When American psychologist Paul Slovic prepared 3 appeals for African

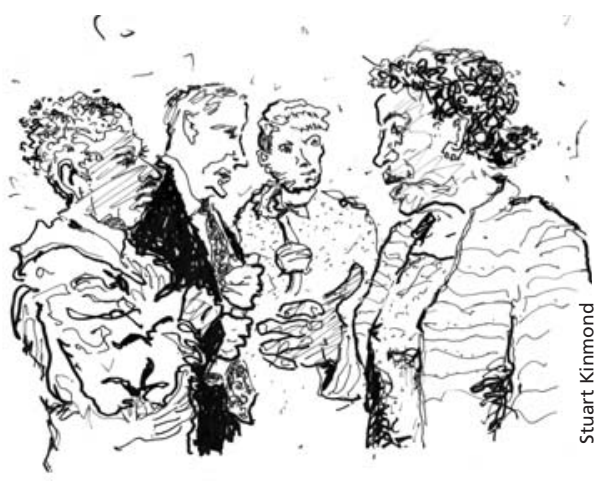

relief - one involving the sad story of a little girl, another with statistics only, and a third combining the story and statistics — he found people actually donated more in response to the first pitch than to the appeal with statistics or even the appeal with the story plus statistics. That is a perfectly irrational result. It's also perfectly predictable once we understand the Stone Age brains behind it.

Journalists who don't make the effort to become numerate, and who allow other aspects of human nature to go unchecked by higher reasoning, make serious mistakes. We see the results in the media every day.

The solution for journalists, as for the rest of the species, is both simple and demanding: we must learn to stop and think.

\section{Dan Gardner}

Journalist and author

Ottawa, Ont.

\section{REFERENCES}

1. Koren G, Kelin N. Bias against negative studies in newspaper reports of medical research. JAMA 1991;226:1824-6

2. Dehaene $\mathrm{S}$. What are numbers really? A cerebral basis for number sense. Technische Universtät Kaiserslautern, Department of Mathematics. Accessed: www.mathematik.uni-kl.de/ wwwfktn /homepage/deHAENE.html (accessed 2008 May 28)

This article is adapted from Risk: The Science and Politics of Fear (2008, McClelland and Stewart).

Have you got an opinion about this article? Post your views at www.cmaj.ca. Potential Salon contributors are welcome to send a query to salon@cma.ca. 